DOI: $10.19195 / 2300-7729.37 .10$

\author{
BERNADETTA GĄGULSKA
}

ORCID: 0000-0002-4665-7214

Biblioteka Główna Uniwersytetu Ekonomicznego w Krakowie

\title{
Gromadzenie kolekcji czasopism w bibliotece akademickiej - współczesne wyzwania
}

\section{Wprowadzenie}

Przed bibliotekami stoi wiele wyzwań, które tkwią w ich dalszym i bliższym otoczeniu. Ponad dwie dekady temu podejście do tematyki gromadzenia wydawnictw ciągłych całkowicie zmieniła Ustawa o zamówieniach publicznych ${ }^{1}$. Ustawa ta była wielokrotnie nowelizowana. Każda większa jej nowelizacja wymagała od bibliotekarzy zajmujących się zakupami nie tylko znajomości tematu i ścisłej współpracy z jednostkami organizacyjnymi uczelni, ale przede wszystkim zmuszała do ciągłego zapoznawania się ze zmianami wielokrotnie pociągającymi za sobą konieczność przeorganizowania działań, opracowania nowych procedur wewnętrznych itp. W ostatnich latach pojawiło się kilka istotnych zagadnień, które zmieniły znacząco politykę gromadzenia zbiorów bibliotek akademickich. Wśród nich wymienić należy takie kwestie, jak: zmiana stawki podatku VAT na książki, czasopisma i elektroniczne źródła informacji, zakupy w ramach konsorcjów, finansowanie z budżetu państwa dostępów konsorcyjnych i baz (tzw. licencja krajowa) oraz dylematy dotyczące wyboru formy nabywanych czasopism - prenumerata wersji drukowanej, tzw. print + online, czy może wyłącznie na nośnikach elektronicznych? Obecnie, wobec zmian finansowania uczelni wyższych ${ }^{2}$ $\mathrm{i}$ — w konsekwencji — szukania jeszcze większych oszczędności we własnych

11994 - Ustawa o zamówieniach publicznych, od 2004 — Ustawa Prawo zamówień publicznych. Uczelnie publiczne są zobligowane do jej stosowania uchwałą Trybunału Konstytucyjnego z dnia 12 marca 1997 roku.

2 Finansowanie działalności statutowej jednostek naukowych w świetle nowelizacji rozporządzenia MNiSW z dnia 21 lipca 2017 roku wprowadziło między innymi nowe zasady przyznawania środków finansowych uczelniom wyższym. Algorytm zmienił sytuację finansową wielu instytucji macierzystych bibliotek akademickich. 
budżetach, olbrzymim wyzwaniem dla bibliotek będzie nie tylko tworzenie nowych, ale i utrzymanie dotychczasowych kolekcji czasopism.

W obliczu coraz surowszych reguł oszczędnościowych przy zakupach zbiorów szczególnie ważne dla bibliotek wydaje się umiejętne rozpoznanie dalszego i bliższego otoczenia. $\mathrm{Z}$ jednej strony zmieniające się przepisy prawa, sytuacja ekonomiczna, rozwój technologiczny wymagają od bibliotekarzy reagowania na dynamikę otoczenia. $\mathrm{Z}$ drugiej strony konieczne jest zbudowanie dobrych relacji z władzami uczelni i społecznością akademicką celem właściwego zaspokojenia potrzeb pracowników, studentów i doktorantów w zakresie literatury. Szansą dla bibliotek w skutecznym pozyskiwaniu zasobów bibliotecznych może być też otwartość na relacje z wydawcami, księgarzami, kolporterami oraz współpraca $\mathrm{z}$ innymi bibliotekami.

Przedmiotem niniejszej analizy jest ukazanie procesu gromadzenia wydawnictw ciągłych w aspekcie polityki budowania własnych kolekcji. Rozważania dotyczą zakupów finansowanych z budżetów jednostek macierzystych bibliotek szkół wyższych, ze szczególnym uwzględnieniem przepisów prawa, sytuacji ekonomicznej, współpracy ze środowiskiem akademickim oraz relacji z kontrahentami.

Celem artykułu jest próba identyfikacji otoczenia bibliotek akademickich i omówienie jego wpływu na funkcjonowanie biblioteki, a w konsekwencji planowe i systematyczne tworzenie kolekcji czasopism. Na przykładzie własnej biblioteki przedstawiono sposób reagowania na zmieniające się otoczenie oraz dostosowanie się do tych zmian.

\section{Polityka gromadzenia zbiorów a otoczenie bibliotek akademickich}

Gromadzenie zbiorów to planowe pozyskiwanie i wprowadzanie do biblioteki właściwych materiałów bibliotecznych. Odbywa się ono drogą kupna, wymiany, darów i egzemplarza obowiązkowego. Opiera się na doborze odpowiednich zasad i środków działania, to jest na właściwej polityce gromadzenia zbiorów, zapewniającej nabycie materiałów zgodnie z profilem, zadaniami i wymaganiami budżetu danej biblioteki ${ }^{3}$. Można śmiało powiedzieć, że gromadzenie zbiorów to jedna z głównych funkcji biblioteki akademickiej. Jej realizacja wymaga, po pierwsze, planowego działania przy uwzględnieniu zasad obowiązujących przy gromadzeniu materiałów bibliotecznych, po drugie, rozpoznania otoczenia bibliotek i reagowania na zachodzące w nim zmiany. Gromadzenie zbiorów jest coraz częściej łączone z pojęciem zarządzania zbiorami. Współcześnie planowe tworzenie kolekcji wymaga połączenia czterech czynności: gromadzenia i uzupełniania zasobów, ich selekcji i zapewnienia czytelnikowi dostępu do zbiorów innych bibliotek

${ }^{3}$ Encyklopedia wiedzy o książce, red. A. Birkenmajer et al., Wrocław 1971, s. 838. 
i dokumentów elektronicznych ${ }^{4}$. Zdaniem J. Wojciechowskiego w organizowaniu procesów bibliotecznych ,ustalając kolejność według następstwa: wszystkie procesy zaplecza inauguruje gromadzenie, na które składa się dobór oraz (pośrednio) zarządzanie zbiorami i usuwanie"5. Procesy zaplecza wymagają bezdyskusyjnie podporządkowania finalnym procesom usługowym ${ }^{6}$.

Zadaniem biblioteki akademickiej jest zaspokojenie potrzeb naukowo-badawczych i dydaktycznych pracowników, studentów i doktorantów. Tematyka gromadzonych zbiorów odzwierciedla profil kierunków kształcenia w danej uczelni. W bibliotekach, które nie otrzymują egzemplarza obowiązkowego, podstawowym źródłem wpływów jest zakup i prenumerata. Pozostałe sposoby nabycia, jak wymiana, dary i egzemplarz obowiązkowy własnych wydawnictw, mają charakter uzupełniający, choć równie istotny. Biblioteka Główna Uniwersytetu Ekonomicznego w Krakowie (BG UEK) gromadzi literaturę z zakresu ekonomii, stosunków międzynarodowych, finansów, prawa, gospodarki i administracji publicznej, towaroznawstwa, zarządzania, czyli przede wszystkim z nauk społecznych, ale także i humanistycznych. Czasopisma pozyskiwane są głównie w drodze prenumeraty, a także wymiany międzyuczelnianej, otrzymanych darów oraz egzemplarza obowiązkowego publikacji własnych Uniwersytetu.

W odniesieniu do wydawnictw ciągłych największym wyzwaniem jest prowadzenie prenumeraty, która determinowana jest przez szereg czynników otoczenia. Z punktu widzenia bibliotekarzy zajmujących się gromadzeniem czasopism niezwykle istotne jest rozpoznanie tego otoczenia i prześledzenie jego wpływu na funkcjonowanie biblioteki, a w rezultacie planowe i konsekwentne tworzenie kolekcji. „Otoczenie bibliotek ${ }^{7}$ dzielimy na otoczenie zewnętrzne i wewnętrzne. Otoczenie zewnętrzne składa się z dwóch warstw: otoczenia ogólnego (dalszego) i otoczenia celowego (bliższego)" 8 .

W otoczeniu zewnętrznym dalszym można wyróżnić sześć wymiarów, które tworzą ogólne warunki dla polityki gromadzenia bibliotek:

1. Ekonomiczny — z punktu widzenia gromadzenia zbiorów szczególną rolę odgrywają środki z budżetu państwa na finansowanie licencji krajowych na do-

${ }^{4}$ Bibliotekarstwo, red. A. Tokarska, Warszawa 2013, s. 131.

5 J. Wojciechowski, Organizacja i zarządzanie w bibliotekach, Warszawa 1998, s. 157.

6 Ibidem.

7 Analizę otoczenia bibliotek przeprowadzili między innymi: M. Huczek, Marketing organizacji non profit, Sosnowiec 2003; T. Kafel, Metoda analizy „partnerów” jako narzędzie monitoringu otoczenia organizacji ,non-profit” (na przykładzie naukowej biblioteki akademickiej), [w:] Wdrażanie nowoczesnych technik zarzadzania w instytucjach non-profit na przykładzie naukowej biblioteki akademickiej: materiały konferencyjne, red. A. Sokołowska-Gogut, Kraków 1998, s. 127-140; B. Gągulska, Otoczenie bibliotek akademickich i jego wpływ na ich funkcjonowanie, [w:] Partnerzy bibliotek. Model komunikacji z otoczeniem, red. I. Jurczak, E. Okularczyk, Łódź 2008, s. 21-31.

8 Por. B. Gągulska, op. cit., s. 23. 
stęp do wybranych baz 9 oraz środki budżetowe przekazywane uczelniom przez Ministerstwo Nauki i Szkolnictwa Wyższego, z których biblioteki mogą tworzyć własne kolekcje.

2. Techniczny — w kontekście budowania kolekcji istotny jest rozwój technologii informacyjnych, w tym: zintegrowanych systemów bibliotecznych, sprzętu komputerowego i oprogramowania, administrowanie siecią, tryb zakupu.

3. Prawno-polityczny - funkcję gromadzenia bibliotek uczelnianych regulują między innymi: Ustawa o bibliotekach, Ustawa Prawo o szkolnictwie wyższym i nauce, Ustawa o obowiązkowych egzemplarzach bibliotecznych, Ustawa Prawo zamówień publicznych oraz dokumenty wewnętrzne, na przykład statut uczelni, regulaminy, zarządzenia.

4. Społeczno-kulturowy — na gruncie bibliotek znaczenie mają preferencje czytelników, na przykład rosnące zapotrzebowanie na wydawnictwa w formie elektronicznej czy pojawienie się nowych narzędzi komunikacyjnych.

5. Międzynarodowy i globalny - dla gromadzenia zbiorów ważna jest na przykład wymiana międzybiblioteczna.

6. Ekologiczny - aspekt środowiskowy w budowaniu kolekcji ma wpływ między innymi na oszczędność papieru, co jest związane ze zwiększającym się zapotrzebowaniem na wydawnictwa elektroniczne.

Otoczenie zewnętrzne bliższe polityce gromadzenia zbiorów dostarcza szeregu użytecznych informacji. Tworzą je grupy organizacji, z którymi biblioteki szkół wyższych powinny kształtować dobre relacje. Można tu wyróżnić następujące jego elementy:

1. Uczelnia wyższa - jednostka macierzysta, której częścią jest biblioteka, a przede wszystkim poszczególne jednostki organizacyjne uczelni: władze uczelni, wydziały lub instytuty, biblioteki wydziałowe lub instytutowe, filie uczelni, organizacje studenckie, rada biblioteczna.

2. Użytkownicy - pracownicy uczelni, doktoranci i studenci.

3. Konkurenci - biblioteki konkurujące o pozyskiwanie środków finansowych, między innymi na elektroniczną archiwizację dokumentów, tworzenie i udostępnianie baz danych oraz zbiorów bibliotecznych nieobecnych na ogólnodostępnych rynkach (,,szara literatura", materiały konferencyjne).

4. Dostawcy - w wypadku bibliotek szkół wyższych są to: wydawnictwa, księgarnie, kolporterzy prasy, dysponenci baz danych.

5. Regulatorzy — w sferze edukacji wyższej działają zewnętrznie między innymi: Ministerstwo Nauki i Szkolnictwa Wyższego (MNiSW), Ministerstwo

9 Środki z budżetu państwa na czasopisma elektroniczne i licencje baz danych to odrębny temat, który omawia między innymi J. Stępniak, Polityka gromadzenia zbiorów elektronicznych od samofinansowania się do licencji krajowych, [w:] Biblioteka w kryzysie czy kryzys w bibliotece? IV Konferencja Biblioteki Politechniki Łódzkiej, Łódź, 15-17 czerwca 2010 r.: materiaty konferencyjne, red. H. Bort-Nowak et al., Łódź 2010, s. 71-83. 
Kultury i Dziedzictwa Narodowego (MKiDN), Państwowa Komisja Akredytacyjna (PKA), a wewnętrznie — władze uczelni.

6. Grupy interesu - organizacją reprezentującą polskie biblioteki akademickie jest Konferencja Dyrektorów Bibliotek Akademickich Szkół Polskich (KDBASP), ponadto o wpływ na działalność bibliotek zabiegają takie organizacje, jak Stowarzyszenie Bibliotekarzy Polskich (SBP) czy Polskie Towarzystwo Informacji Naukowej (PTIN).

7. Partnerzy strategiczni — w budowaniu kolekcji istotną rolę odgrywają fundacje i konsorcja bibliotek, na przykład Poznańska Fundacja Bibliotek Naukowych, Konsorcjum Bibliotek Kierunków Ekonomicznych.

Otoczenie wewnętrzne biblioteki akademickiej składa się z warunków i sił wewnątrz biblioteki. Obejmuje jej kadrę kierowniczą, pracowników oraz zasoby finansowe, rzeczowe i informacyjne ${ }^{10}$.

\section{Wpływ uwarunkowań prawnych na tworzenie kolekcji czasopism w bibliotece akademickiej}

Obowiązek gromadzenia i opracowania zbiorów nakłada na omawiane instytucje Ustawa o bibliotekach. W ustępie 1 artykułu 4 czytamy: „Do podstawowych zadań bibliotek należy: gromadzenie, opracowywanie, przechowywanie i ochrona materiałów bibliotecznych" 11 . W świetle Ustawy Prawo o szkolnictwie wyższym i nauce z dnia 20 lipca 2018 roku biblioteki akademickie wykonują statutowe cele uczelni. Artykuł 11 ustawy stanowi, iż do podstawowych zadań uczelni należy ,upowszechnianie i pomnażanie osiągnięć nauki i kultury, w tym przez gromadzenie i udostępnianie zbiorów bibliotecznych, informacyjnych i archiwalnych"12. Statut uczelni określa zadania biblioteki, do których zaliczamy między innymi gromadzenie zbiorów bibliotecznych. Według Statutu Uniwersytetu Ekonomicznego w Krakowie (paragraf 3):

Do zadań Biblioteki Głównej należy gromadzenie, opracowywanie, przechowywanie i udostępnianie zbiorów bibliotecznych, a także sprawowanie nadzoru merytorycznego nad działalnością pozostałych bibliotek uczelnianych, przy współdziałaniu kierowników jednostek organizacyjnych, przy których biblioteki zostały utworzone ${ }^{13}$.

10 Por. B. Gągulska, op. cit., s. 26.

11 Dz.U. 2018, poz. 574.

12 Dz.U. 2018, poz. 1668.

13 Por. Załącznik nr 3 do Statutu Uniwersytetu Ekonomicznego w Krakowie, Organizacja i zasady korzystania ze zbiorów systemu biblioteczno-informacyjnego Uniwersytetu Ekonomicznego w Krakowie. 
Przy zakupach materiałów do księgozbioru biblioteki akademickie są zobowiązane do stosowania Ustawy Prawo zamówień publicznych (Pzp) ${ }^{14}$ i rozwiązań wewnętrznych (w uczelniach są to regulaminy zamówień publicznych oraz ustalone zasady finansowania zakupów). W kwietniu 2014 roku weszła w życie kolejna nowelizacja Pzp, z którą biblioteki szkół wyższych wiązały ogromne nadzieje, gdyż miała znacznie uprościć i przyspieszyć zakup nowości wydawniczych ${ }^{15}$. Nowelizacja wprowadziła zmiany w Ustawie z dnia 30 kwietnia 2010 roku o zasadach finansowania nauki oraz w Ustawie z dnia 25 października 1991 roku o organizowaniu i prowadzeniu działalności kulturalnej, które określały zasady udzielania zamówień wyłączonych z reżimu przepisów Pzp. W rzeczywistości interpretacja przepisów nie dopuściła do bezprzetargowego zamawiania czasopism, jeśli szacunkowa wartość zamówienia netto przekracza wyrażoną w złotych równowartość kwoty 30 tysięcy euro.

W BG UEK zakup książek, czasopism i baz danych odbywa się w oparciu o Pzp, Regulamin udzielania zamówień publicznych w Uniwersytecie Ekonomicznym w Krakowie (RUZP) ${ }^{16}$, plan rzeczowo-finansowy i wszelkie bieżące informacje rozsyłane przez władze Uczelni. Zgodnie z Regulaminem BG jest realizatorem w zakresie koordynowanych zamówień na

Dostawy (również w wersji elektronicznej): książek (z zastrzeżeniem § 9 RUZP), czasopism, gazet (w tym suplementów do nich), katalogów, poradników, przewodników, wydawnictw cyklicznych, wydawnictw wymienno-kartkowych, itp. Usługi: introligatorskie (oprawa książek, czasopism, gazet, dyplomów, wykonanie tekturowych teczek na czasopisma, itp.), usługi dostępu do bibliotecznych baz danych, usługi wypożyczeń międzybibliotecznych ${ }^{17}$.

Zakupy wydawnictw ciągłych prowadzi Oddział Gromadzenia Zbiorów. W związku z tym, że prenumerata czasopism wymaga przygotowania planu zamówień publicznych, na początku każdego roku kalendarzowego zbierane jest zapotrzebowanie od jednostek organizacyjnych Uniwersytetu. Na tej podstawie ustala się szacunkową wartość zamówienia oraz sporządza listy tytułów gazet i czasopism do zaprenumerowania. Przy uaktualnianiu wykazów czasopism oprócz tytułów zgłoszonych przez poszczególne jednostki bierze się pod uwagę utrzymanie ciągłości prenumeraty czasopism naukowych udostępnianych

14 Ustawa z dnia 29 stycznia 2004 roku Prawo zamówień publicznych, tekst jednolity, Dz.U. 2018, poz. 1986.

${ }^{15} \mathrm{O}$ tej i wcześniejszych nowelizacjach szerzej: H. Kowalska, Zakupy materiałów bibliotecznych pod rzadami ustawy Prawo zamówień publicznych (1997-2014), [w:] Biblioteki we wspótczesnym systemie prawnym Polski i Unii Europejskiej: VI Konferencja Naukowa Korporacji Bibliotekarzy Wrocławskich, red. J. Czyrek, B. Górna, Wrocław 2014, s. 37, http://www.dbc.wroc.pl/ dlibra/docmetadata?id=26089\&from=\&dirids=1\&ver_id=\&lp=1\&QI= [dostęp: 4.01.2018].

${ }^{16}$ Zarządzenie Rektora Uniwersytetu Ekonomicznego w Krakowie z dnia 8 stycznia 2018 roku, nr R-0201-1/2018 w sprawie zmiany Regulaminu Udzielania Zamówień Publicznych w Uniwersytecie Ekonomicznym w Krakowie oraz tekst jednolity Regulaminu Udzielania Zamówień Publicznych.

17 Ibidem, par. 3. 
w BG. W miarę możliwości finansowych, to jest wielkości środków przyznanych Bibliotece na zakup czasopism, uwzględniane są nowości wydawnicze, oferty wydawców oraz propozycje pracowników naukowo-dydaktycznych i studentów. Wszystkie tytuły czasopism proponowane do prenumeraty przedstawiane są do akceptacji członkom Rady Bibliotecznej. Wykaz pozytywnie zaopiniowanych tytułów trafia na listy do zaprenumerowania. Zakupy czasopism zagranicznych w UEK odbywają się poprzez przetarg nieograniczony ${ }^{18}$. Przy zakupie czasopism polskich obowiązuje procedura udzielania zamówień publicznych poniżej 30 tysięcy euro (artykuł 4 punkt 8 Pzp), uregulowana w paragrafie 6 Regulaminu. Od 2015 roku ma tutaj zastosowanie procedura zapytania ofertowego.

Obowiązujące procedury zamówień publicznych przy zakupach czasopism sprzyjają konkurencyjności, a składane oferty są coraz bardziej atrakcyjne. Konieczność powtarzania co roku przetargu nieograniczonego na czasopisma zagraniczne oraz zapytania ofertowego na dostawę czasopism polskich ma też słabe strony. Minusem takiej sytuacji jest to, że co roku może to być inny dostawca. Zmiana dostawcy rodzi na ogół dodatkowe trudności, na przykład ryzyko niekompletności dostaw czasopism drukowanych i przerw w dostępie do czasopism elektronicznych, zwłaszcza na początku roku kalendarzowego. Wiąże się z tym konieczność organizowania (często na nowo) dostępów do czasopism elektronicznych, administrowania adresami IP i hasłami, systematycznego sprawdzania dostępów i zgłaszania reklamacji.

\section{Wpływ uwarunkowań ekonomicznych na tworzenie kolekcji czasopism w bibliotece akademickiej}

Od wielu lat w uczelniach wyższych z jednej strony obserwujemy stały wzrost cen czasopism naukowych, głównie zagranicznych czy specjalistycznych, a z drugiej wielkość budżetu przyznanego bibliotece na zakup wydawnictw ciągłych $\mathrm{i}$ baz danych jest stała lub z każdym rokiem maleje. W praktyce oznacza to zakup mniejszej liczby tytułów i egzemplarzy. Uczelnie, zmuszone ciąć koszty, często szukają bowiem oszczędności w bibliotekach, między innymi w wydatkach na zbiory. Przy zdecydowanie skromniejszych środkach finansowych dotychczasowe działania dotyczące polityki gromadzenia zbiorów w wielu bibliotekach mogą stać się niewystarczające do utrzymania kolekcji czasopism na poziomie zadowalającym ich użytkowników.

W Uniwersytecie Ekonomicznym w Krakowie budżet przyznawany BG na zakup wydawnictw ciągłych w ciągu kilku ostatnich lat systematycznie się zmniejszał. Utrzymanie ciągłości prenumeraty uznanych i wartościowych czasopism naukowych, z uwzględnieniem stałego wzrostu cen oraz potrzeb społeczności

18 Ibidem, par. 5. 
akademickiej (na przykład na nowości wydawnicze, nowe tytuły dla uruchamianych kierunków studiów), wymagało stopniowych decyzji o rezygnacji z części prenumerowanych tytułów. Dodatkowo potrzeba racjonalizacji wydatkowanych środków na prenumeratę skłania do permanentnej weryfikacji zasadności kupowanych wydawnictw. W zakresie polityki gromadzenia zbiorów wprowadzone zostały następujące działania oszczędnościowe:

- rezygnacja z dubletów czasopism,

— rezygnacja z wersji drukowanej tytułów czasopism w wolnym dostępie,

- rezygnacja z wersji drukowanej czasopisma na rzecz dostępu online ${ }^{19}$,

- rezygnacja z czasopism rzadko wykorzystywanych.

Część oszczędności wynikała ze zmian na rynku wydawniczym; niektóre tytuły czasopism (zwłaszcza polskich wydawców) przestały się ukazywać lub pojawiły się w wolnym dostępie.

Kolejnym tematem są bardzo wysokie koszty prenumeraty czasopism zagranicznych. Przy braku perspektyw na większe budżety bibliotek oraz z uwagi na stale rosnące ceny wydawnictw kluczowe wydają się zakupy konsorcyjne, a także przychylna polityka MNiSW w zakresie ich dofinansowania. Uruchomione w 2009 roku finansowanie w 100\% licencji krajowych na dostęp do wybranych baz spowodowało w uczelniach wyższych obniżenie budżetów na zakup zbiorów dokonywanych bezpośrednio przez biblioteki ${ }^{20}$.

Przy kalkulacji cen czasopism importowanych niewątpliwie ogromną rolę odgrywają konsorcja bibliotek i licencje krajowe. Instytucje uczestniczące w konsorcjach mają uprawnienia do zakupu czasopism w wersji drukowanej po cenach obniżonych (Deep Discount Price, DDP) dostępnych w ramach wszystkich licencji krajowych na bazy elektroniczne, dotowane z budżetu państwa. UEK korzysta z rabatów następujących wydawców: Elsevier, Springer Verlag oraz Kluwer Academic Publishers, Wiley, Oxford Journals (kolekcja „Economics \& Finance”), Cambridge University Press (CUP).

Znaczne koszty generuje prenumerata krajowej prasy drukowanej, a zwłaszcza dzienników. Sposobem na znalezienie oszczędności może okazać się subskrypcja prasy cyfrowej. Choć nie jest to regułą, w wielu wypadkach wersja cyfrowa jest oferowana w cenie niższej od ceny edycji papierowej ${ }^{21}$.

Istotną kwestią jest stawka podatku VAT na czasopisma elektroniczne. Obecnie jest to $23 \%$. Niewątpliwą korzyścią dla bibliotek byłoby obniżenie stawki podatku VAT do poziomu stawki na czasopisma w wersji drukowanej.

19 Tu dodatkowa oszczędność na oprawie i magazynowaniu.

20 Szerzej: J. Stępniak, op. cit., s. 81.

21 Szerzej: A. Jachimczyk, Elektroniczne gazety i czasopisma: sposób na oszczędności w bibliotekach?, [w:] Biblioteki i ich klienci: między płatnym a bezplatnym komunikowaniem się w erze zasobów cyfrowych i sieci, red. M. Kocójowa, Kraków 2009, s. 112-120 (= seria III „,Publikacje Instytutu INiB UJ" 6), http://www.inib.uj.edu.pl/wydawnictwa-iinib-uj/seria-3/06 [dostęp: 4.01.2018]. 


\section{Współpraca biblioteki ze środowiskiem akademickim}

Utrzymanie dobrych relacji z władzami uczelni i ze społecznością akademicką jest niezbędnym czynnikiem w rozwijaniu kolekcji czasopism. Osoby podejmujące decyzję muszą rozumieć potrzebę funkcjonowania biblioteki i doceniać jej rolę w strategii rozwoju uczelni. Na politykę gromadzenia zbiorów może oddziaływać także PKA, która oceniając zasoby biblioteczne pod kątem zapewnienia wysokiej jakości kształcenia, wymusza na uczelni zmiany mające wpływ na politykę gromadzenia, na przykład w zakresie ich wartości dydaktycznej i koniecznej liczby egzemplarzy dla studentów. $Z$ dodatkowymi argumentami za podniesieniem oceny bibliotecznej obsługi studentów łatwiej jest przekonać władze do konieczności wyposażenia biblioteki w potrzebną literaturę przy uruchamianiu nowych kierunków kształcenia.

Jeśli chodzi o społeczność akademicką, nasuwają się tutaj dwie kwestie. Po pierwsze, ważne są działania mające na celu informowanie pracowników i studentów o posiadanych zasobach, nowościach, a także prowadzenie statystyk i analiz stopnia wykorzystania poszczególnych tytułów czasopism i baz. Te działania mogą okazać się bardzo istotne podczas podejmowania decyzji na przykład o zaprzestaniu prenumeraty tytułu czy rezygnacji z jakiegoś na rzecz bardziej przydatnego. Mogą one polegać między innymi na:

- prezentowaniu prenumerowanych czasopism w gablotach wystawowych,

— przeglądzie nowości i zamieszczaniu informacji o nich na stronie domowej biblioteki czy w wydawnictwach uczelnianych,

— informowaniu o nowych tytułach pracowników i studentów pocztą elektroniczną, ukowej,

— prowadzeniu zajęć z przysposobienia bibliotecznego oraz informacji na-

- prowadzeniu i analizowaniu statystyk wykorzystania poszczególnych wydawnictw ciągłych,

- zbieraniu informacji na temat stopnia wykorzystywania prasy w ogóle (obserwacje na dyżurach, ankiety, wywiady).

Ostatnie zadanie jest łatwiejsze do wykonania, gdy w jednym oddziale skupione jest zarówno gromadzenie, jak i udostępnianie pozyskiwanych wydawnictw. $\mathrm{W}$ przeciwnym razie konieczna jest wymiana informacji pomiędzy oddziałami biblioteki i pracownikami.

Po drugie, konieczne jest zapewnienie ciągłości prenumeraty czasopism dla istniejących kierunków studiów, zbudowanie kolekcji dla kierunków uruchamianych, a także nabywanie nowości rynkowych. W tym celu można przygotować odpowiednie narzędzia, które ułatwią czy wręcz umożliwią kontakt użytkownika z biblioteką. Na przykład w UEK propozycje prenumeraty gazet i czasopism, zarówno krajowych, jak i zagranicznych, dla Biblioteki, które byłyby przydatne 
w procesie dydaktycznym, można zgłaszać za pośrednictwem zakładki „Zgłoś do zakupu”, znajdującej się na głównej stronie katalogu komputerowego.

Niewątpliwie istotną rolę doradczą w tworzeniu kolekcji mogą odegrać różnego rodzaju gremia, rady, na przykład wydziału, biblioteczne, czy wybrani do tego celu konsultanci. W zakresie prenumeraty rada biblioteczna może pełnić funkcję doradczą w podejmowaniu decyzji między innymi o:

- zakupie nowych tytułów czasopism bądź dostępu do baz danych,

- rezygnacji z edycji drukowanych prasy na rzecz wersji elektronicznych,

- rezygnacji z prenumerowanych tytułów czasopism.

Jeśli chodzi o politykę gromadzenia, w wypadku wątpliwości co do zaprzestania prenumeraty wydawnictwa pomocną w podjęciu decyzji może okazać się Komisja do spraw Selekcji Zbiorów.

\section{Kształtowanie relacji z kontrahentami}

Ważnym elementem w podejmowaniu decyzji o zakupach materiałów bibliotecznych są relacje z wydawcami, księgarzami i dystrybutorami prasy. Biblioteki mogą współpracować z wydawcami, na przykład poprzez udostępnianie użytkownikom wersji elektronicznych, druk „na żądanie” pojedynczych egzemplarzy, negocjowanie rabatów. Zmienia się również polityka wydawców wobec prenumeratorów. Coraz częściej oferują oni tańsze kopie cyfrowe będące odzwierciedleniem edycji papierowej, umożliwiają dostęp online do prenumerowanych czasopism drukowanych, coraz więcej publikują czasopism elektronicznych o dostępie nieograniczonym.

Niezwykle istotną grupę partnerów dla bibliotek stanowią dostawcy prasy. $\mathrm{W}$ wypadku prenumeraty czasopism współpraca $\mathrm{z}$ kolporterem trwa przez cały okres obowiązywania umowy ${ }^{22}$. Na bibliotekarzach spoczywa między innymi obowiązek opracowania faktur, reklamacje, naliczanie kar umownych za nieterminowe dostawy, stąd tak ważne jest doprecyzowanie zapisów umowy. Jeśli mówimy o realizacji dostaw prasy, istotne jest określenie: przedmiotu umowy, czasu jej obowiązywania z zastrzeżeniem uzupełnienia tytułów wydanych z opóźnieniem, miejsca i godzin dostarczania prasy, formy i wymaganych terminów realizacji dostaw. Dla czasopism drukowanych dobrze jest wskazać terminy dostaw z uwzględnieniem częstotliwości ukazywania sięe23. Dla czasopism elektronicznych konieczne są zapisy o zobowiązaniu dostawcy do opłacenia prenumeraty instytucjonalnej i uruchomieniu dostępów online we wskazanym terminie, zapewnieniu bieżącego, aktualizowanego pełnotekstowego dostępu i zagwarantowaniu dostępu do archiwum z lat poprzednich, a w wypadku jego braku lub utrudnień

22 Umowy zawierane są najczęściej na rok kalendarzowy, rzadziej na dwa lub trzy lata.

23 Krótszy termin można przyjąć dla dzienników, dłuższy dla tygodników, miesięczników itd. 
w dostępie elektronicznym do czasopism - przywróceniu dostępu i określeniu czasu na usunięcie usterki.

Dobrze jest zastrzec ciągłość prenumeraty tytułu, niezależnie od nośnika, w wypadku zmiany wersji z drukowanej na wyłącznie elektroniczną. Istotne jest też informowanie o wszelkich zmianach wydawniczych, to jest opóźnieniach wydawniczych, zawieszeniach wydawania czasopism, zmianach tytułów i ich częstotliwości, dodatkach, zeszytach specjalnych. W wypadku czasopism importowanych ważne jest zapewnienie elektronicznej bieżącej obsługi prenumeraty i reklamacji w trybie online. W umowie, oprócz zapisów dotyczących wynagrodzenia dla dostawcy, warto zastrzec zachowanie cen jednostkowych wskazanych w ofercie przez cały okres obowiązywania umowy oraz warunki i termin płatności. W temacie reklamacji należy zwrócić uwagę na: terminowe uzupełnianie brakujących numerów czasopism, dostarczanie egzemplarza zastępczego za egzemplarz z wadą techniczną lub uszkodzony. Niezbędne jest określenie wysokości i zakresu kar umownych oraz okoliczności, na podstawie których można odstąpić od ich naliczania.

\section{Zakończenie}

Na zakończenie słów kilka o kompetencjach, jakie musi posiadać osoba zajmująca się zakupami wydawnictw ciągłych w bibliotece akademickiej. W rzeczywistości polskich bibliotek niejednokrotnie jeden oddział, a w nim zaledwie kilka osób, odpowiada za całe spektrum skomplikowanych zadań: pozyskanie czasopism zgodnie z obowiązującymi procedurami wewnętrznymi, koordynowanie prac związanych z zastosowaniem przepisów Prawa zamówień publicznych w kontekście organizacji przetargów na prenumeratę czasopism dla wszystkich jednostek uczelni, sporządzanie planu zamówień publicznych, przygotowanie dokumentacji przetargowej (wzorów umów, specyfikacji), współpracę z przedstawicielami środowisk w zakresie zapotrzebowania na wydawnictwa, terminowe przygotowanie faktur dla kwestury, prowadzenie ewidencji wpływów oraz sprawozdawczości.

Reasumując, coraz skromniejsze środki finansowe nie zwalniają bibliotek $z$ dostosowania oferty do potencjalnych potrzeb swoich środowisk akademickich. Taka sytuacja wymaga ściślejszej współpracy ze społecznością akademicką, przedstawicielami wydziałów, instytutów, organizacji studenckich celem poznania potrzeb naukowo-badawczych i dydaktycznych pracowników, studentów, doktorantów oraz właściwego na nie reagowania. Szansą na uzupełnianie prenumeraty może być ukierunkowana i racjonalna wymiana biblioteczna oraz pozyskiwanie darów i gospodarowanie drukami egzemplarzy zbędnych. Tu ważną rolę może odegrać współpraca bibliotek. 


\section{Bibliografia}

Adamiak K., Bródka M., Gromadzenie jako zaplecze kształtowania marki na przykładzie Biblioteki Uniwersyteckiej w Poznaniu, [w:] Biblioteka jako marka: materiały z VII Forum Młodych Bibliotekarzy w Łodzi 11-12 września 2012 r., red. J. Stawińska, Warszawa 2013, s. 73-79, http://www.wbc.poznan.pl/publication/335369 [dostęp: 4.01.2018].

Bibliotekarstwo, red. A. Tokarska, Warszawa 2013.

Encyklopedia wiedzy o ksiażce, red. A. Birkenmajer et al., Wrocław 1971.

Gągulska B., Otoczenie bibliotek akademickich i jego wpływ na ich funkcjonowanie, [w:] Partnerzy bibliotek. Model komunikacji z otoczeniem, red. I. Jurczak, E. Okularczyk, Łódź 2008, s. 21-31.

Hollender H., Gromadzenie po macoszemu, „Forum Akademickie” 2009, nr 4, dod. „Forum Książki" 2009, nr 1 (43), s. 6-8.

Huczek M., Marketing organizacji non profit, Sosnowiec 2003.

Jachimczyk A., Elektroniczne gazety i czasopisma: sposób na oszczędności w bibliotekach?, [w:] Biblioteki i ich klienci: między płatnym a bezpłatnym komunikowaniem się w erze zasobów cyfrowych $i$ sieci, red. M. Kocójowa, Kraków 2009, s. 112-120 (= seria III „ePublikacje Instytutu INiB UJ" 6), http://www.inib.uj.edu.pl/wydawnictwa-iinib-uj/seria-3/06 [dostęp: 4.01.2018].

Jazdon A., Zdobądź i... pozbądź się, czyli uwag kilka o problemach zarządzania zbiorami w Polsce, [w:] Rola i funkcje nowoczesnej biblioteki akademickiej: materiały z konferencji zorganizowanej z okazji 50-lecia UMK, 27-29 września 1995 r., red. J.M. Day, M. Śliwińska, Toruń 1996, s. $179-190$.

Kafel T., Metoda analizy ,partnerów” jako narzędzie monitoringu otoczenia organizacji „,non-profit" (na przykladzie naukowej biblioteki akademickiej), [w:] Wdrażanie nowoczesnych technik zarządzania w instytucjach non-profit na przykładzie naukowej biblioteki akademickiej: materiały konferencyjne, red. A. Sokołowska-Gogut, Kraków 1998, s. 127-140.

Kowalska H., Zakupy materiatów bibliotecznych pod rządami ustawy Prawo zamówień publicznych (1997-2014), [w:] Biblioteki we współczesnym systemie prawnym Polski i Unii Europejskiej: VI Konferencja Naukowa Korporacji Bibliotekarzy Wrocławskich, red. J. Czyrek, B. Górna, Wrocław 2014, s. 37-39, http://www.dbc.wroc.pl/dlibra/docmetadata?id=26089\&from=\&dirids=1\&ver_id=\&lp=1\&QI= [dostęp: 4.01.2018].

Stępniak J., Polityka gromadzenia zbiorów elektronicznych — od samofinansowania się do licencji krajowych, [w:] Biblioteka w kryzysie czy kryzys w bibliotece? IV Konferencja Biblioteki Politechniki Łódzkiej, Łódź, 15-17 czerwca 2010 r.: materiały konferencyjne, red. H. Bort-Nowak et al., Łódź 2010, s. 71-83.

Strategie gromadzenia zbiorów w bibliotekach polskich: materiały z IV Ogólnopolskiej Konferencji Naukowej Pobierowo, 15-17 września 2011, red. U. Ganakowska, M. Różycka, Szczecin 2012.

Strzelecka-Żyromska A., Marciniak R., Nyga K., Polityka w zakresie gromadzenia zbiorów w Bibliotece Głównej Uniwersytetu Medycznego w Poznaniu w Analizie SWOT, „Forum Bibliotek Medycznych" 6, 2013, nr 2 (12), s. 493-506.

Wojciechowski J., Biblioteki akademickie: obszary kooperacji, „Przegląd Biblioteczny” 2012, z. 4, s. $477-490$.

Wojciechowski J., Organizacja i zarządzanie w bibliotekach, Warszawa 1998.

Wojciechowski J., Z problemów organizacji zasobów bibliotecznych, „Przegląd Biblioteczny” 1998, z. 1, s. 5-15. 


\title{
Akty prawne
}

Ustawa z dnia 27 czerwca 1997 roku O bibliotekach, tekst jednolity, Dz.U. 2018, poz. 574.

Ustawa z dnia 29 stycznia 2004 roku Prawo zamówień publicznych, tekst jednolity, Dz.U. 2018, poz. 1986.

Ustawa z dnia 20 lipca 2018 roku Prawo o szkolnictwie wyższym i nauce, Dz.U. 2018, poz. 1668.

Zarządzenie Rektora Uniwersytetu Ekonomicznego w Krakowie z dnia 8 stycznia 2018 roku, nr R-0201-1/2018 w sprawie zmiany Regulaminu Udzielania Zamówień Publicznych w Uniwersytecie Ekonomicznym w Krakowie oraz tekst jednolity Regulaminu Udzielania Zamówień Publicznych.

\section{Acqusition of a periodicals collection in the academic library - modern challenges}

\begin{abstract}
Summary
In the article, on the example of the Main Library of the Cracow University of Economics, experience in the field of collection policy of serials publications was presented. The influence of selected elements of the nearer and more distant library environment on creating periodicals collections in academic libraries is discussed. Particular attention has been paid to the legal and economic conditions of library purchasing activities, as well as to cooperation with many elements of the library environment in the field of creating periodicals collections.
\end{abstract}

KEYWORDS: library environment, academic libraries, acquisition of serial publications, serials subscription policies 